XX Міжнародний симпозіум «Методи дискретних особливостей в задачах математичної фізики/Discrete Singularities Methods in Mathematical Physics», МДОЗМФ/DSMMPh-2021

УДК 532.5.6

MSC 76S05

\title{
Transversely streamlined cylinder on rigid surface
}

\author{
V.A. Voskoboinick ${ }^{1}$, O.A. Voskoboinyk ${ }^{1}$, A.M. Onishchenko ${ }^{2}$, \\ A.V. Voskobijnyk ${ }^{1}$ \\ ${ }^{1}$ Institute of hydromechanics NAS Ukraine, Kyiv, Ukraine \\ ${ }^{2}$ National Transport University, Kyiv, Ukraine \\ E-mail:vlad.vsk@gmail.com
}

\begin{abstract}
The results of experimental studies are presented in order to study the features of the formation of separated and vortex flows in the vicinity of a transversely streamlined cylinder on the surface of a hydraulically smooth rigid surface and to determine the space-time characteristics of sources of wall pressure fluctuations. The studies were carried out in laboratory conditions on transversely streamlined cylinders, which were located on a rigid surface. The field of wall pressure fluctuations was measured by a group of miniature piezoceramic pressure fluctuation sensors, which were installed flush with the streamlined rigid surface in front of the cylinder and in its wake. The research results were processed and analyzed using the mathematical apparatus of the theory of probability and mathematical statistics. The spectral and correlation characteristics of the separated flow in the vicinity of a transversely streamlined cylinder are obtained.
\end{abstract}

Key words: cylinder, flat surface, pressure fluctuation sensors, spectrum, correlation, vortex structures.

\section{Поперечне обтікання циліндра на жорсткій поверхні}

\author{
В.А. Воскобійник ${ }^{1}$, О.А. Воскобойник ${ }^{1}$, А.М. Оніщенко ${ }^{2}$ \\ А.В. Воскобійник ${ }^{1}$ \\ ${ }^{1}$ Інститут гідромеханіки НАН України, Київ, Україна \\ ${ }^{2}$ Національний університет транспорту, Київ, Україна \\ E-mail:vlad.vsk@gmail.com
}

Наведено результати експериментальних досліджень 3 метою вивчення особливостей формування відривних і вихрових течій в околі поперечно обтічного циліндра на поверхні гідравлічно гладкою жорсткої поверхні і визначення просторово-часових характеристик джерел пульсацій пристінного тиску. Дослідження проведені в лабораторних умовах на поперечно обтічних циліндрах, які були розташовані на плоскій жорсткій поверхні. Поле пульсацій пристінного тиску вимірювалося групою мініатюрних п’єзокерамічних датчиків пульсацій тиску, які були встановлені врівень з обтічної жорсткою поверхнею перед циліндром і в його слід. Результати досліджень оброблялися і аналізувалися за допомогою математичного апарату теорії ймовірності та математичної статистики. Установлено, що інтенсивність пульсацій пристінного тиску в відривних областях в околі поперечно обтічного циліндра в кілька разів вища, ніж в умовах обтікання гідравлічно гладкої поверхні. 3 віддаленням понад 100 діаметрів поперечно обтічного циліндра прикордонний шар відновлюється. Виявлено, що зі збільшенням діаметра поперечно обтічного циліндра і 3 наближенням до кормової частини циліндра рівні спектрів збільшуються. Зі збільшенням діаметра циліндра збільшуються низькочастотні компоненти пульсацій тиску, які генеруються великомасштабними вихровими структурами. Когерентність поля пульсацій пристінного тиску зменшується зі збільшенням діамет-

(c) Voskoboinick V.A., Voskoboinyk O.A., Onishchenko A.M., Voskobijnyk A.V., 2021 
ра циліндра, а фаза взаємного спектра лінійно змінюється в області низьких частот. Установлено, що зі збільшенням відстані між датчиками корелованість пульсацій тиску зменшується, через виродження дрібномасштабних вихорів, і максимуми коефіцієнта кореляції мають місце при більшому часу затримки. У сліді поперечно обтічного циліндра великомасштабні вихрові структури переносяться з більш високою швидкістю, ніж дрібномасштабні вихори.

Ключові слова: циліндр, плоска поверхня, датчики пульсацій тиску, спектр, кореляція, вихрові структури.

\section{Introduction}

Cross flow over cylinders is widely used in practice. Trunk pipelines, optical communication lines, sealed cable sheaths cross a large number of rivers, seas and oceans. Often, cylindrical structures are located on rigid solid surfaces and are subject to currents that cause oscillations and vibrations of streamlined cylinders. When the frequencies of the forced vibrations coincide with the frequencies of the natural vibrations of cylindrical structures, resonance phenomena arise that cause significant loads on the structures and lead to emergency situations.

The study of sources of oscillations and vibrations of transversely streamlined cylindrical surfaces and the development of means to reduce their effect on structures is carried out in many countries. The formation of a complex vortex flow in the vicinity of such bodies, its nonstationarity and inhomogeneity significantly complicate the numerical and physical modeling. The random process of vortex formation, velocity and pressure fields, and vibration characteristics requires the use of modern means and methods of research $[1,2]$.

The aim of this work is to study the features of the formation of separated and vortex flows in the vicinity of a transversely streamlined cylinder on the surface of a hydraulically smooth rigid surface and to determine the space-time characteristics of sources of wall pressure fluctuations.

\section{Program and research methodology}

The study of the features of the formation of a separated flow in the vicinity of a transversely streamlined cylinder located on a rigid surface was carried out using physical modeling methods. The flow diagram over a rigid wall with a transverse cylinder and the location of the wall pressure fluctuation sensors are shown in Fig. 1. An unfavorable pressure gradient leads to separation of the boundary layer in front of the cylinder. Behind the cylinder, the boundary layer is attached to the rigid surface. A complex vortex motion is formed in the areas of separation of the boundary layer. Periodically, largescale vortex structures are detached from the aft surface of the cylinder, at the appropriate Reynolds numbers, and are carried away by the current. Intense fluctuations of velocity and pressure are generated in the areas of separation and reattachment of the boundary layer $[3,4]$. The separation of vortex structures and velocity and wall pressure fluctuation fields cause vibrations of the streamlined surface and oscillations of the transversely streamlined cylinder. Large non-stationary loads often lead to emergency situations on trunk pipelines and fiber-optic communication lines. 


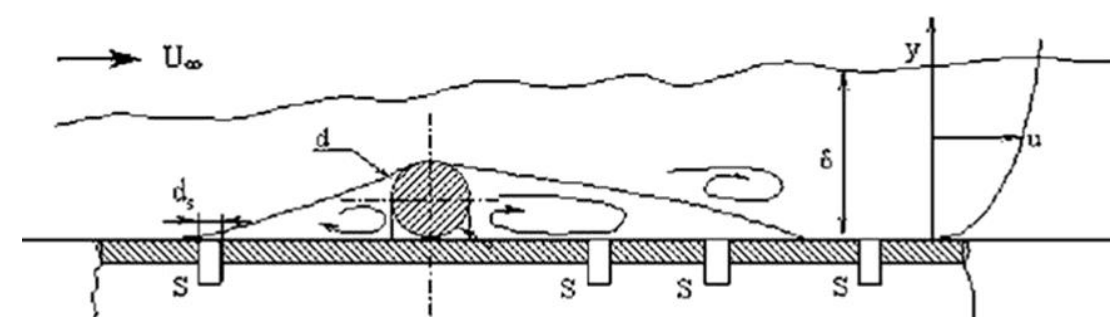

Fig. 1. Scheme of the flow over a transversely streamlined cylinder and the installation locations of the wall pressure fluctuation sensors.

Experimental studies were carried out in the hydrodynamic flume [2, 5]. The field of wall pressure fluctuations in the vicinity of a transversely streamlined cylinder was investigated using miniature pressure fluctuation sensors. The sensors had a sensitive surface diameter $d_{s}=1.3 \mathrm{~mm}$ and were installed flush with the streamlined surface in front of the cylinder and behind it $[2,3]$. The group of sensors made it possible to determine the integral, spectral and correlation characteristics of the pressure fluctuation field, to study the features of the generation and evolution of the vortex flow, the inhomogeneity and nonstationarity of separation regions in the vicinity of the cylinder.

The processing and analysis of experimental data was carried out using the mathematical apparatus of the theory of probability and mathematical statistics [1, 6]. The rootmean-square values of pressure fluctuations were determined as:

$$
p_{r m s}^{\prime}(x, t)=\sqrt{\overline{p^{2}(x, t)}}=\sqrt{R_{p}(0,0)}=\left[\int_{0}^{\infty} P(0, f) d f\right]^{1 / 2},
$$

where $x$ is the longitudinal coordinate, $t$ is the time, $f$ is the frequency, $R(0,0)$ is the autocorrelation, and $P(0, f)$ is the spectral power density of the wall pressure fluctuations. The power spectral densities of the wall pressure fluctuations were calculated from the dependence:

$$
P(\omega)=\frac{1}{2 \pi} \int_{-\infty}^{\infty} R_{p}(0, \tau) e^{-j \omega \tau} d \tau=\frac{1}{\pi} \int_{0}^{\infty} R_{p}(0, \tau) \cos (\omega \tau) d \tau,
$$

where $\omega=2 \pi f$ is the circular frequency, $\tau$ is the delay time. The cross power spectral density of the pressure fluctuations between the two sensors was calculated as:

$$
\mathrm{P}_{12}(\xi, \omega)=\frac{1}{\pi} \int_{0}^{\infty} \mathrm{R}_{12}(\xi, \tau) \exp (-\mathrm{j} \omega \tau) \mathrm{d} \tau=\left|\mathrm{P}_{12}(\xi, \omega)\right| \exp (-\mathrm{j} \Theta(\xi, \omega))
$$

where $\xi$ is the separation between the sensors, $\mathrm{R}_{12}(\xi, \tau)$ is the cross-correlation and $\Theta(\xi, \omega)$ is the phase of the cross-spectrum. The cross correlation of the wall pressure fluctuations between the two sensors was determined by the dependence:

$$
\mathrm{R}_{12}(\xi, \tau)=\frac{1}{\mathrm{~T}} \int_{0}^{\mathrm{T}} \mathrm{p}^{\prime}\left(\mathrm{x}_{1}, \mathrm{t}\right) \mathrm{p}^{\prime}\left(\mathrm{x}_{2}, \mathrm{t}\right) \mathrm{dt},
$$

where $\mathrm{x}_{1}$ and $\mathrm{x}_{2}$ are the coordinates of the near-wall pressure pulsation sensors. The cross-correlation coefficient was determined according to the dependence:

$$
\rho_{12}(\xi, \tau)=R_{12}(\xi, \tau) / p^{\prime}\left(x_{1}, t\right) p^{\prime}\left(x_{2}, t\right) .
$$



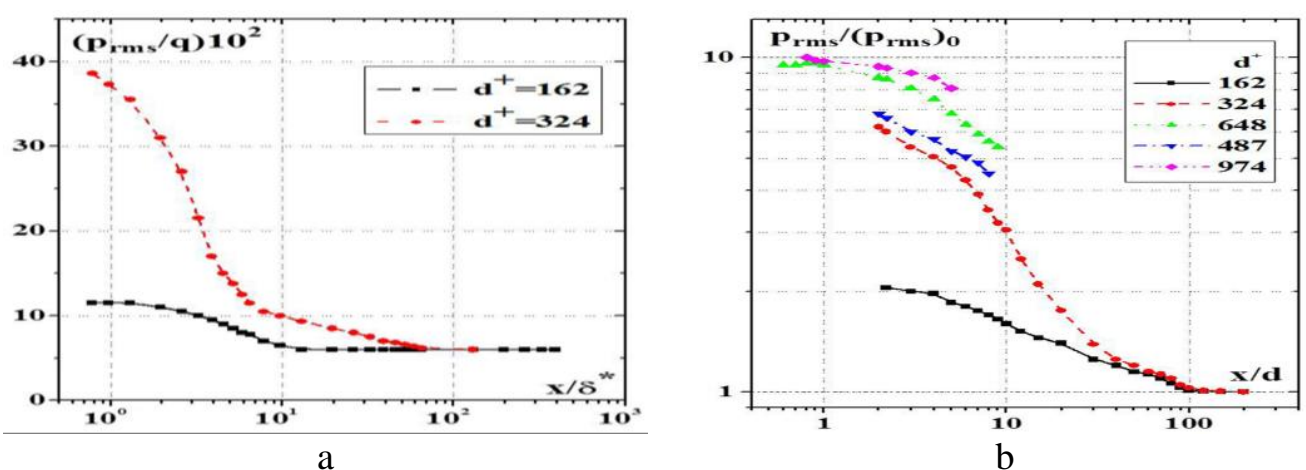

Fig. 2. Pressure fluctuation sensors (a) and experimental setup (b).

\section{Research results}

The research results showed that the intensity of the wall pressure fluctuations in the separation regions in the vicinity of the transversely streamlined cylinder became several times higher than in the flow on a hydraulically smooth plate. For large cylinder diameters and Reynolds numbers, this difference exceeded several orders of magnitude. Fig. 2 shows the values of the intensity of the wall pressure fluctuations in the wake of the cylinder. Fig. 2a shows the rms values of pressure fluctuations (1), which are normalized by dynamic pressure $q=\rho U^{2} / 2$, where $\rho$ is the water density and $U$ is the flow velocity, depending on the distance from the cylinder to the measurement point $x / \delta^{*}$, where $\delta^{*}$ is the displacement thickness of the boundary layer. Curve 1 was obtained for cylinder diameter $d^{+}=U d / v=162$, where $v$ is the kinematic coefficient of viscosity, curve 2 was measured for $d^{+}=324$. Fig. $2 \mathrm{~b}$ shows the rms pressure fluctuations, which are normalized by the rms pressure fluctuations on a smooth plate, depending on the distance in the cylinder wake. Curve 1 was measured for a cylinder with a diameter of $d^{+}=162$, curve $2-d^{+}=324$, curve $3-d^{+}=648$, curve $4-d^{+}=487$ and curve $5-d^{+}=974$. Curves 1-3 are measured for the Reynolds number $\operatorname{Re}_{L}=U L / v=5 \cdot 10^{5}$, where $L$ is the distance from the nose of the plate to the location of the cylinder. Curves 4 and 5 are measured for $\operatorname{Re}_{L}=1 \cdot 10^{6}$. The results of the studies showed that with the removal of more than 100 diameters of the transversely streamlined cylinder, the boundary layer is restored.
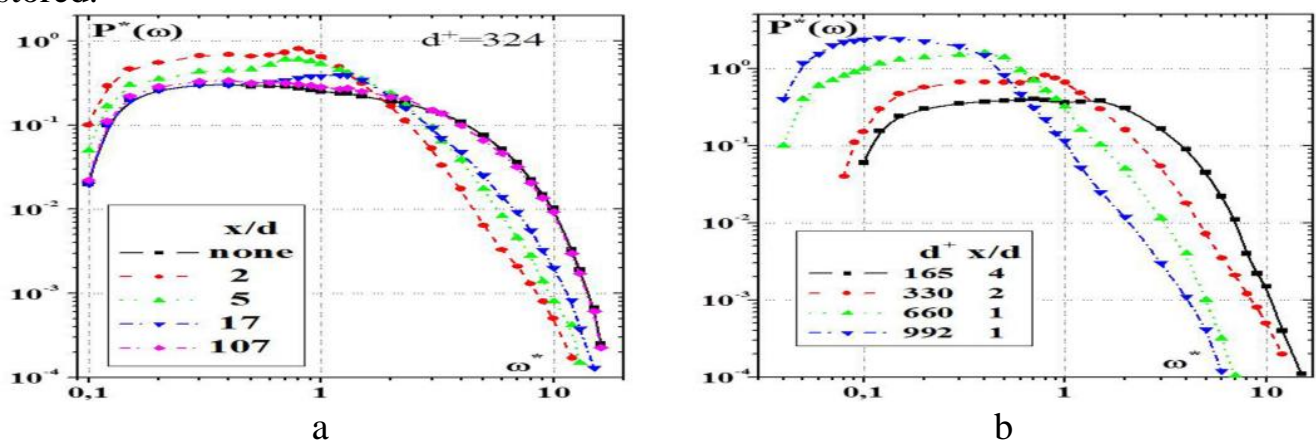

Fig. 3. Power spectral density of the wall pressure fluctuations for cylinder $\mathrm{d}^{+}=324$ (a) and different cylinders (b). 
XX Міжнародний симпозіум «Методи дискретних особливостей в задачах математичної фізики/Discrete Singularities Methods in Mathematical Physics»,

МДОЗМФ/DSMМPh-2021

Fig. 3a presents the results of measuring the spectra of pressure fluctuations (2), which are normalized by external variables in the form $P^{*}(\omega)=P(\omega) U /\left(\overline{p^{2}(x, t)} \delta^{*}\right)$, depending on the frequency $\omega^{*}=2 \pi f \delta^{*} / U$. Here curve 1 is measured on a smooth surface without a cylinder, and the rest of the curves are measured for different distances from the cylinder with a diameter of $d^{+}=324$. Fig. $3 b$ shows the power spectral densities of the wall pressure fluctuations, which were measured in the wake of cylinders of different diameters. The low-frequency components of pressure fluctuations, which are generated by large-scale vortex structures [7], are increased in the separation regions of the boundary layer behind large-diameter cylinders.

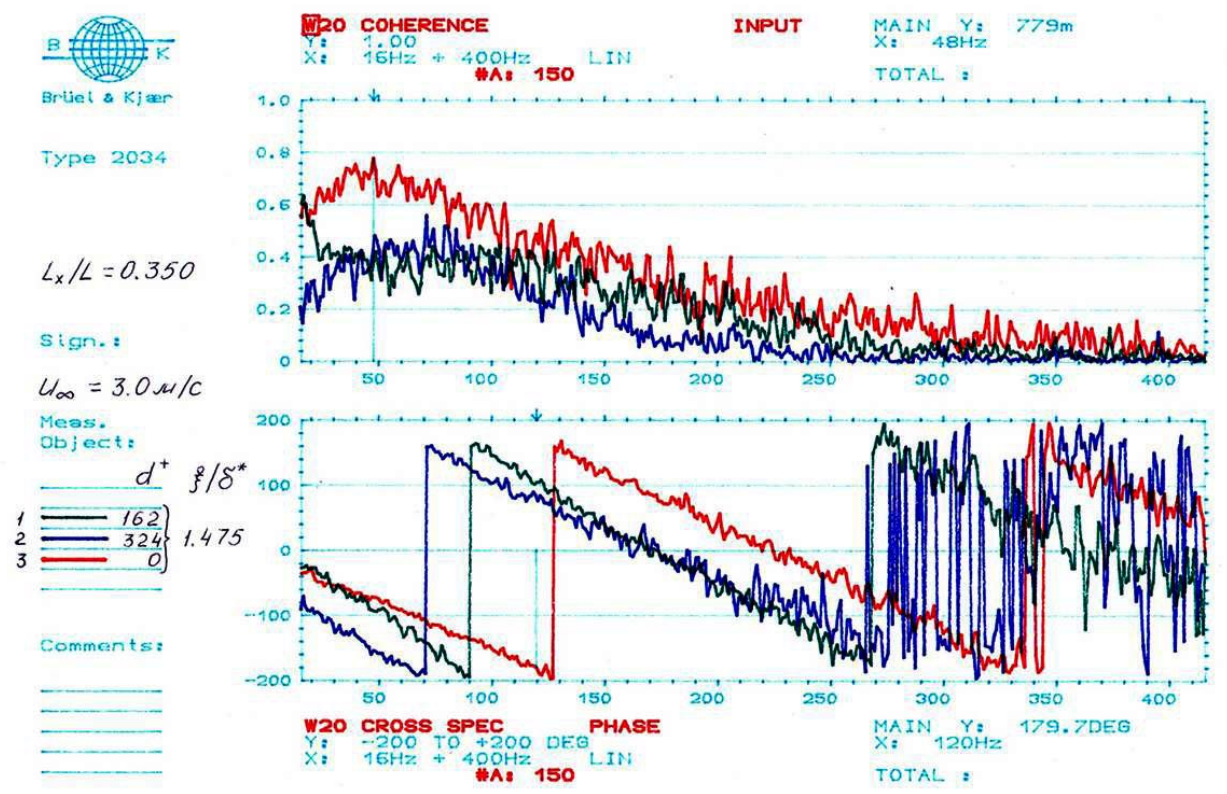

Fig. 4. Coherence function and phase of the mutual spectrum of wall pressure fluctuations.

Fig. 4 shows the coherence function, which was calculated from the dependence $\gamma_{12}^{2}(\xi, \omega)=\left|\mathrm{P}_{12}(\xi, \omega)\right| / \mathrm{P}_{1}(0, \omega) \mathrm{P}_{2}(0, \omega)$, and the phase of the mutual spectrum (3) as a function of frequency for a flow velocity of $3 \mathrm{~m} / \mathrm{s}$ and the location of the cylinder relative to the plate length $\mathrm{L}_{\mathrm{x}} / \mathrm{L}=0.35$. Curve 1 was measured in the near wake of a cylinder with a diameter of $d^{+}=162$, curve 2 - for $d^{+}=324$, and curve 3 was measured on the surface of a hydraulically smooth surface without a cylinder. The cross spectra were measured by a pair of sensors located at a distance of $\xi / \delta^{*}=1.475$ from each other in the direction perpendicular to the longitudinal axis of the cylinder. A linear change in the phase of the cross spectrum made it possible to calculate the phase convective velocity of vortex structures, which generate the wall pressure fluctuations according to the dependence $U_{\mathrm{cp}}=-2 \pi \mathrm{f} \xi / \theta_{12}(\xi, \omega)$. 


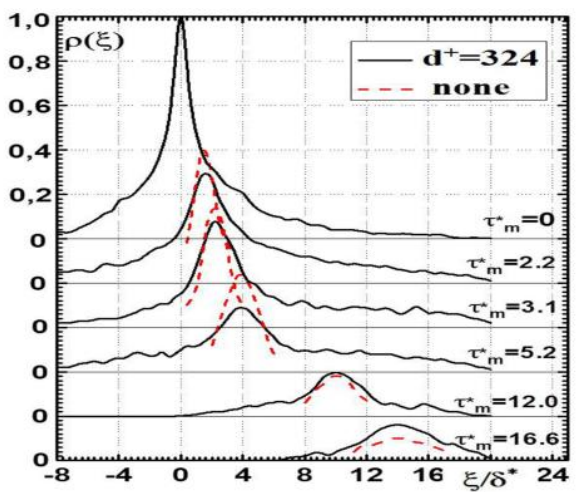

a

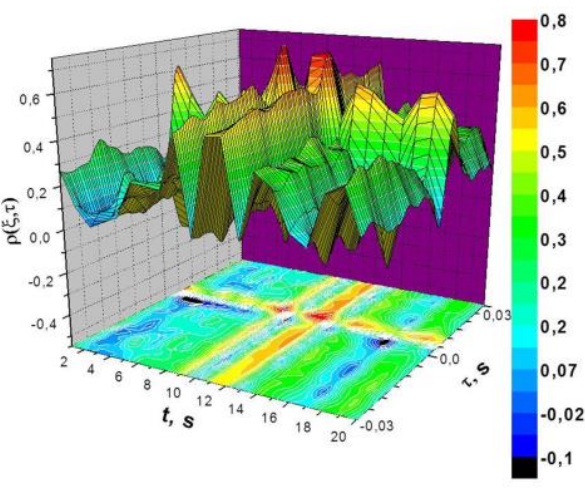

$\mathrm{b}$

Fig. 5. Cross-correlation coefficients (a) and correlogram (b).

The coefficients of cross or space-time correlations of the wall pressure fluctuations between two sensors, which were located in the wake of the transversely streamlined cylinder and were calculated using dependencies (4) and (5), and the correlogram, which represents the change in the correlation coefficients in time, are shown in Fig. 5. With an increase in the distance between the sensors, the correlation of pressure fluctuations was decreased and the maxima of the correlation coefficient took place at a longer delay time. Areas of increasing and decreasing correlations are observed alternately in the correlogram (Fig. 5b). The group velocity of the transfer of vortex structures was determined from the dependence $\mathrm{U}_{\mathrm{cg}}=\xi / \tau_{\max }$, where and $\tau_{\max }$ is the delay time for which the maximum of the cross-correlation was observed $[6,8]$.
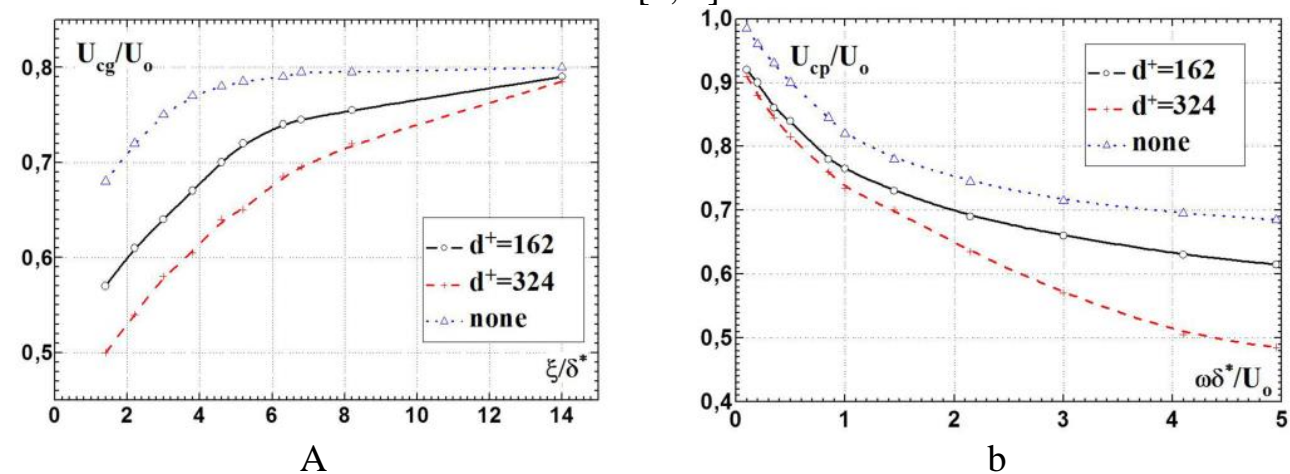

Fig. 6. Group transfer velocity of the correlated sources of wall pressure fluctuations (a) and their phase convective velocity (b).

The group and phase convective velocities of correlated or coherent wall pressure fluctuations are shown in Fig. 6. The group velocity of vortex structures (Fig. 6a), which generate the wall pressure pulsations, was increased with increasing distance between the sensors. With an increase in the distance between the observation points, large-scale vortex structures remain correlated, which are transferred at higher velocities. As the frequency increases, the coherence (Fig. 4) and the phase convective velocity (Fig. 6b) of vortex structures decrease, since this frequency range is generated by small-scale vortices, which are located closer to the streamlined surface. 
XX Міжнародний симпозіум «Методи дискретних особливостей в задачах математичної фізики/Discrete Singularities Methods in Mathematical Physics», МДОЗМФ/DSMMPh-2021

\section{Conclusion}

The main structures in separated flow are vortices. Vortex structures interact with each other and the streamlined surface and generate intense fields of velocity and pressure fluctuations. The intensity of the wall pressure fluctuations is increased with an increase in the cylinder diameter and with an approach to its aft surface. Large-scale vortex structures prevail behind the cylinder, which generate low-frequency fluctuations and have a higher transfer velocity than small-scale vortices.

\section{REFERENCE}

1. Bendat J.S., Piersol A.G. Random Data: Analysis and Measurement Procedures. NY: Willey, 2010. $640 \mathrm{p}$.

2. Voskoboinick V., Kornev N., Turnow J. Study of near wall coherent flow structures on dimpled surfaces using unsteady pressure measurements. Flow Turbulence Combust. 2013. Vol. 90, № 4. P. 709-722. https://doi.org/10.1007/s10494-012-9433-9

3. Voskoboinick V.A., Grinchenko V.T., Makarenkov A.P. Pseudo-sound behind an obstacle on a cylinder in axial flow. Intern. J. Fluid Mech. Res. 2005. Vol. 32, № 4. P. 488-510. https://doi.org/10.1615/InterJFluidMechRes.v32.i4.60

4. Voskoboinick V.A., Turick V.N., Voskoboinyk O.A. et al. Influence of the Deep Spherical Dimple on the Pressure Field Under the Turbulent Boundary Layer. Advances in Computer Science for Engineering and Education. ICCSEEA 2018. Advances in Intelligent Systems and Computing. 2019. Vol754. P. 23-32. https://doi.org/10.1007/978-3-319-91008-6_3

5. Voskoboinick V.A., Voskoboinick A.A., Turick V.N., Voskoboinick A.V. Space and time characteristics of the velocity and pressure fields of the fluid flow inside a hemispherical dimple generator of vortices. J. Eng. Physics and Thermophysics. 2020. Vol. 93, № 5. P. 1205-1220. https://doi.org/10.1007/s10891-020-02223-3

6. Vinogradnyi G.P., Voskoboinick V.A., Grinchenko V.T., Makarenkov A.P. Spectral and correlation characteristics of the turbulent boundary layer on an extended flexible cylinder. J. Fluid Dyn. 1989. Vo. 24, № 5. P. 695-700.

7. Voskoboinick V.A., Makarenkov A.P. Spectral characteristics of the hydrodynamical noise in a longitudinal flow around a flexible cylinder. Intern. J. Fluid Mech. Res. 2004. Vol. 31, № 1. P. 87-100.

8. Voskoboinick V.A., Grinchenko V.T., Makarenkov A.P. Correlation characteristics of a wall pressure fluctuation field in a turbulent boundary layer induced by a longitudinal flow along a flexible extended cylinder. Intern. J. Fluid Mech. Res. - 2003. Vol. 30, № 6. P. 644-650. 


\title{
Поперечное обтекание цилиндра на жесткой поверхности
}

\author{
В.А. Воскобойник ${ }^{1}$, А.А. Воскобойник ${ }^{1}$, А.Н. Онищенко ${ }^{2}$, \\ А.В. Воскобойник ${ }^{1}$ \\ ${ }^{1}$ Институт гидромеханики НАН Украины, Киев, Украина \\ ${ }^{2}$ Национальный университет транспорта, Киев, Украина \\ E-mail:vlad.vsk@gmail.com
}

Приведены результаты экспериментальных исследований с целью изучения особенностей формирования отрывных и вихревых течений в окрестности поперечно обтекаемого цилиндра на поверхности гидравлически гладкой жесткой поверхности и определения пространственно-временных характеристик источников пульсаций пристеночного давления. Исследования проведены в лабораторных условиях на поперечно обтекаемых цилиндрах, которые были расположены на гидравлически гладкой жесткой поверхности. Поле пульсаций пристеночного давления измерялось группой миниатюрных пьезокерамических датчиков пульсаций давления, которые были установлены заподлицо с обтекаемой поверхностью пластины перед цилиндром и в его следе. Результаты исследований обрабатывались и анализировались с помощью математического аппарата теории вероятности и математической статистики. Установлено, что интенсивность пульсаций пристеночного давления в отрывных областях в окрестности поперечно обтекаемого цилиндра в несколько раз стала выше, чем в условиях обтекания гидравлически гладкой поверхности. С удалением более 100 диаметров поперечно обтекаемого цилиндра пограничный слой восстанавливается. Обнаружено, что с увеличением диаметра поперечно обтекаемого цилиндра и с приближением к кормовой части цилиндра уровни спектров увеличиваются. С увеличением диаметра цилиндра увеличиваются низкочастотные компоненты пульсаций давления, которые генерируются крупномасштабными вихревыми структурами. Когерентность поля пульсаций пристеночного давления убывает с увеличением диаметра цилиндра, а фаза взаимного спектра линейно изменяется в области низких частот. Установлено, что с увеличением расстояния между датчиками коррелированность пульсаций давления уменьшается, из-за вырождения мелкомасштабных вихрей, и максимумы коэффициента корреляции имеют место при большем времени задержки. В следе поперечно обтекаемого цилиндра крупномасштабные вихревые структуры переносятся с более высокой скоростью, чем мелкомасштабные вихри.

Ключевые слова: цилиндр, плоская поверхность, датчики пульсаций давления, спектр, корреляция, вихревые структуры. 